\title{
RACISM TOWARDS AFRICAN AMERICAN COMMUNITY \\ AS REFLECTED IN MAYA ANGELOU'S I KNOW WHY THE CAGED BIRD SINGS: BLACK AESTHETIC CRITICISM
}

\author{
Gisa Maya Saputri \\ e-mail: gisamaya94@mail.ugm.ac.id
}

\begin{abstract}
The study of the African American community always circulates among the issues of race, racism, discrimination, slavery, and oppression. All these issues become the grand themes of African American literature. These literary works could be studied and covered under the scope of Black Aesthetic criticism. One of the prominent works of African American literature is an autobiography of Maya Angelou entitled $I$ Know Why the Caged Bird Sings (1969). This autobiography portrays Angelou's childhood experiences which brings up the issues of race, racism, and oppression. This paper aims to analyze the kinds of racism experienced by the African American community and their struggle against it as depicted in the book. To provide a thorough discussion of the matter, critical race theory was employed as the method of analysis. The result is drawn based on the basic tenets of critical race theory proposed by Richard Delgado and Jean Stefancic (2001); everyday racism, interest convergence, the social construction of race, differential realization, intersectionality, and voice of Color. The findings show the struggle of African American community against racism which are expressed through the act of ignorance, promoting intelligence, communal efforts, resistance, promoting social movement, and stepping forward to voice their experience through African American literature.
\end{abstract}

Article information

Received: 26 August, 2021

Revised: 09 September, 2021

Accepted: 23 September, 2021

Keywords: Black Aesthetic criticism; race; racism; Maya Angelou; critical race theory

DOI $\quad$ : https://doi.org/10.22146/rubikon.v8i2.69687

Available at https://jurnal.ugm.ac.id/rubikon/article/view/69687

This work is licensed under a Creative Commons Attribution-ShareAlike 4.0 International License

\section{INTRODUCTION}

African American community experiences a wide range of occurrences that shape their ways of perceiving the world. The vast majority of African Americans were brought to America and forced to work as slaves. This initial experience leads to the tradition of suppression. African American turns into an oppressed group while the White exercises their power over them in the situation of systemic oppression. This situation 
depicts any unjust treatment where "one group denies another group access to the resources of society" (Collins, 2000, p. 4). According to Collins (2000), some factors act as the major catalysts for oppression, including race, class, gender, sexuality, nation, age, and ethnicity (p. 4). African Americans struggle to develop their community and position themselves in American society which has a long history of racism (Tidwell, 1990). Historically, the root of racism, particularly towards African Americans, lies in the belief that African Americans should be excluded from social, political, and economic participation as well as exploited for economic gain because that is part of the natural order (Tidwell, 1990). Tidwell (1990) argues that this belief, which is articulated during the Jim Crow era, has caused America to pay for the cost of racism; starting from sociopolitical, economic, to cultural cost. Culturally, African Americans must deal with discriminatory treatments, including suppression of the intellectual tradition. Scott (1985) states that the act of suppressing the knowledge of any oppressed group eases the dominant group to rule because it indicates that "subordinate groups willingly collaborate in their own victimization" (as cited in Collins, 2000, p. 3). This historical binary black/white paradigm indeed meets with criticism and invites further discussion. Guess (2006) states that scholars have problematized the duality of race which is socially constructed and widely analyzed to show how most Americans perceive race (p. 670). On one hand, most White Americans think of racism as a thing of the past since they neither believe it nor feel guilty about it (McConahay et al., 1981, p. 578). On the other hand, modern racism theories suggest that "there is a kind of racism in America that takes the form of racial prejudice plus traditional, conservative values" (Sniderman et al., 1991, p. 423). Considering those two perspectives, without limiting others, there are enough proofs that African Americans experience life differently from their White counterparts. Thus, they are working for a way to voice their experience, including their struggle, to wider communities. One of the ways is through literature, which could be analyzed further under the scope of Black Aesthetic criticism. All these historical bakgrounds cause much of African American literature deals with racism, including the work of Maya Angelou entitled $I$ Know Why the Caged Bird Sings (1969).

I Know Why the Caged Bird Sings is the first out of seven autobiographies of Maya Angelou who is known as an American poet, award-winning author, as well as civil rights activist (Bauer \& Wightman, 2020). She is an African American woman whose works explore various themes ranging from economic, racial, to sexual oppression. I Know Why the Caged Bird Sings explores those themes, particularly Angelou's struggle to fight for liberation from racism and misogyny (Sethi, 2013). The title of this book is taken from a poem entitled Sympathy by one of Angelou's favorite writers, Paul Laurence Dunbar, an African American poet. It reflects a bird that is stuck in a cage. Yet, more specifically, the big theme of this poem is about a lack of freedom. It stands in line with the theme of Angelou's autobiography. Angelou describes her life from the age of 3 to 16 in which she experienced such a traumatic childhood and led her to turn into an insecure black girl. The issues described in Angelou's autobiography also cover rape and racism. Angelou does not only focus on the traumatic events of her childhood, but she also explores her strength to be an African American woman. This literary work was aimed as a way 
to cope with her struggle against racism and oppressed society (Bauer \& Wightman, 2020). To put it in a wider context, this autobiography works not merely as a depiction of an African American woman's life, but also as a portrayal of African American's struggle, in general, in dealing with oppressed society. Besides, this work was published in 1969; a period when Black Aesthetic criticism started to emerge from the mid-1960s to the early 1970s (Leitch, 2010, p. 421). Thus, this work does not only focus on Angelou's struggle as an individual, but it also portrays the life struggle of the African American community in general. Based on those reasons, I Know Why the Caged Bird Sings by Maya Angelou is relevant to be discussed as a way for African Americans to gain their voice through literature. Furthermore, this work of African American literature could be discussed under the scope of Black Aesthetic criticism.

The works of literature are ranging from written form; poem and novel, for instance, to oral form; as in drama and songs. Literature itself is considered an art that people could enjoy through their senses. This art comes as a result of creative processes. On the other hand, literary study differs from literature since it deals more with science rather than art (Wellek \& Warren, 1954, p. 3). One of the methods in literary study involves literary criticism which aims to research literary works based on theory and practice "with matters of opinion and faith" (Wellek \& Warren, 1954, p. 31). Literary criticism, particularly in America since the 1930s, experiences a struggle between the formalistic school of criticism and cultural-based criticism. The former focuses on linguistic, rhetorical, as well as epistemological ways of thinking, while the latter covers the sociological, psychological, and political realm in analyzing the literary works (Leitch, 2010, p. 13). One of the types of literary criticism which emphasizes more on cultural-based criticism is Black Aesthetic criticism.

As could be inferred from its name, Black Aesthetic criticism deals with Black art. Black art in this context is defined as any literary works which are created by African American artists and responsible for their community (Leitch, 2010, p. 421). Black art's standard is rooted in African American communal life in which it is considered to be entirely different from White-Euro American aesthetic. Since almost all of literary criticism that has emerged previously is derived from White and Eurocentric perspective, African American critics work on the ideas of creating a specific method to analyze Black art. This method is considered essential among the African American community as a way to achieve unity and strength based on their cultural root (Leitch, 2010, p. 421). This paper aims to analyze the kinds of oppression done by the Whites to the African American community, as depicted in the work of Maya Angelou; I Know Why the Caged Bird Sings (1969). Moreover, the ways taken by the African American community to fight against oppression is also discussed. To achieve a comprehensive discussion in the matter, the method of Black Aesthetic criticism is employed.

In order to meet the goal of this paper and provide a thorough explanation of the topic being discussed, the Black Aesthetic mode of criticism is employed as the main method of analysis. This criticism focuses on literary works of African American artists which portray the original experience of their community. In analyzing the literary work of Maya Angelou entitled I Know Why the Caged 
Bird Sings (1969), the sociological, historical, and cultural approaches are also being employed as the supporting method. These approaches are in line with Cruse's judgment that African American situations should be seen through many sides which could then lead to specific approaches (as cited in Leitch, 2010, p. 430). Moreover, in analyzing African American literary works, Cullen and Hughes, African-American writers, highlight the political views and the social role of African American writers in an oppressed and racist society since those matters could influence the literary style of the writers (as cited in Tyson, 2006, p. 364).

In particular, this study employs the critical race theory as an approach in discussing the matter. This theory first emerged as a critique of constitutional law as well as humanities (Delgado \& Stefancic, 2001, p. 3; Ladson-Billings, 1998, p. 7). Since this paper aims to analyze the sociological, historical, and cultural background of White oppression to the African American community, the critical race theory as a critique of humanity is deeply performed. As could be inferred from its name, this theory deals more with the topic which is relevant to race (Tyson, 2006, p. 368). Tyson (2006) states that this theory examines the matter of race which is reflected in everyday lives and studies common assumptions about race that concerning racism (p. 369). Specifically, the means of critical race theory which is proposed by Richard Delgado and Jean Stefancic (2001) is being employed for deepening the analysis in this research. Delgado and Stefancic (2001) emphasize the ways the African American community experiences life differently because of their race (p. 10). In developing this theory, Delgado and Stefancic (2001) offer some basic tenets which are agreed by many critical race theorists (p. 6). There are six basic tenets of the critical race theory, according to Delgado and Stefancic, which becomes the foundation of analyzing the topic of study:

a. Everyday racism; racism does not always happen in more visible forms as physical or verbal attacks of people of color or the oppression by white supremacist groups, but it could also happen in more emotionally draining and stress-provoking forms as in the everyday lives of people of color.

b. Interest convergence; the practice of racism often converges, or overlaps, with the interest or desires of the Whites. These interests and desires depict how dominant society practices racism since they are willing to advance themselves financially and to feel better psychologically.

c. The social construction of race; race is portrayed as socially rather than biologically produced since it reflects the beliefs and definitions about race at different times. The beliefs and definitions of race change when economic and social pressure change.

d. Differential racialization; this term describes how dominant society racializes or defines the racial characteristics of different minority groups at different times.

e. Intersectionality; race does not stand alone in defining an individual, yet it intersects with other notions as gender, class, sexual and political orientation, and personal history to form the identity of each individual.

f. Voice of Color; it refers to a belief that minority thinkers and writers have a better position rather than the Whites to voice up as well as write and speak about race and 
racism since they have the first-hand experience on the matters (p. 6-9).

All those tenets of critical race theory by Delgado and Stefancic (2001) are explored and discussed thoroughly to meet the objectives of the study.

\section{DISCUSSION}

\section{Basic Tenets of Critical Race Theory in Portraying Black's Struggle against Racism and Oppression}

\section{Know Why the Caged Bird Sings} (1969) depicts some kinds of racism and oppression done by the Whites to African American community. Besides, this book also delivers the ways taken by the African American community to fight against racism and oppressed society. Both issues are presented through the elaboration of six basic tenets of critical race theory which are proposed by Delgado and Stefancic (2001) to portray the African American community's struggle against racism and oppression, based on Maya Angelou's I Know Why the Caged Bird Sings (1969).

\section{a. Everyday Racism}

The setting of time in this autobiography is from the 1930s through the 1950s. This time depicts a great political and economic condition that badly influences the life of African Americans; the Great Depression and the New Deal. The condition worsened the situation of the African American community in any field, ranging from economic to racist culture. Angelou (1969) describes the first assumption of the African American community about the Great Depression that "it was for whitefolks, so it had nothing to do with them" (p. 50). African American community thought they would not be hit by the Depression as seriously as the Whites, yet soon they realized that the Depression did not discriminate. Economically, the African American community experienced difficulties in selling their main products, such as cotton, since the White owners dropped the payment:

The Depression must have hit the white section of Stamps with cyclonic impact, but it seeped into the Black area slowly, like a thief with misgivings. ... I think that everyone thought that the Depression, like everything else, was for the whitefolks, so it had nothing to do with them. ... It was when the owners of cotton fields dropped the payment of ten cents for a pound of cotton to eight, seven and finally five that the Negro community realized that the Depression, at least, did not discriminate (Angelou, 1969, pp. 50-51).

Culturally, everyday racism increased to the point that the African American community was treated differently only because of their skin color. Angelou depicts the way a group of powhitetrash kids treated her grandmother badly which then resulted in her lifelong paranoia of the Whites. The powhitetrash was a term used by Angelou in her book to portray the poverty-stricken white. Her grandmother, whom she called Momma in the book, was mocked by those powhitetrash kids who basically were at the same age as Angelou. They were aping Momma and made fun of her only because they accidentally met her and she was black.

They came finally to stand on the ground in front of Momma. At first they pretended seriousness. Then one of them wrapped her right arm in the crook of her left, pushed out her mouth and started to hum. I realized that she was apping my grandmother. Another said, "Naw, Helen, you ain't standing like her. This here's it." Then she lifted her chest, folded her arms and mocked that strange 
carriage that Annie Henderson (Angelou's grandmother). Another laughed, "Naw, you can't do it. Your mouth ain't pooched out enough. It's like this." (Angelou, 1969, pp. 30-31)

This type of racism becomes a common act that happened on an everyday basis during that era of the Great Depression. This act was seen as the Whites' way to cope with the difficult situation; although they were not in a good shape economically, they considered themselves to be in a better shape than the African American community. In facing that kind of racism, Momma, as a reflection of most African American community at that time, tried to ignore it by focusing on doing other activities to divert her attention away. Momma kept singing a song at a steady pace to steady her nerves until the powhiterash kids stopped their action.

... I could see that the arms of Momma's apron jiggled from the vibrations of her humming. But her knees seemed to have locked as if they would never bend again. She sang on. No louder than before, but no softer either. No slower or faster. (Angelou, 1969, p. 31)

This act of ignorance of the African American community while they were experiencing everyday racism by the Whites performed as their struggle against racism, for they could control themselves and did not easily get provoked by it. Collins (2000) argues that the act of ignorance and silence should not be regarded as submissiveness, yet it is a form of consciousness that raises the inside ideas (p. 98). In the modern time, along with the legacy of historical activism through either social movement or Black art, African American community starts to gain courage to stand for their rights and voice. Eventually, their past experience of racial discrimination is seen as a wake up call for their community to voice up while controling themselves at the same time.

\section{b. Interest Convergence}

Interest convergence reflects the Whites' ways of performing racism which converges with their interest to be advanced than the African American community. Angelou depicts this tenet with a situation in which she felt humiliated by the Whites during her graduation. Angelou and her brother, along with most African American kids in her area, attended the black school in town named Lafayette County Training School. This school was predominantly occupied by African American community, starting from its students to its teachers and school workers. Angelou shared her experience in her school which also developed her character as she started to understand her identity as African American. The realization of how her race was despised by majority group flooded in when she had her graduation. Graduation became an event which had been waited by not only the prospective graduates but also the whole family and community. Angelou (1969) even described that, "( $\mathrm{t}$ )he children in Stamps trembled visibly with anticipation. Some adults were excited too, but to be certain the whole young population had come down with graduation epidemic" (p. 169). However, this moment of joy turned into bitterness as the Whites tried to approach African American community for the sake of their mere interest. It was shown by two White men, one of them was Mr. Edward Donleavy, who suddenly came to Angelou's graduation. At first, he seemed to praise African American kids and the community as a whole in his speech. He even offered betterment for their school in particular. 
He told us of the wonderful changes we children in Stamps had in store. The Central School (naturally, the White school was Central) had already been granted improvements that would be in use in the fall. ... He went on to praise us. He went on to say how he had bragged that "one of the best basketball players at Fist sank his first ball here at Lafayette County Training School." (Angelou, 1969, pp. 178-179)

His speech had a tendency to give a proper appreciation for African American community, particularly as an example to the kids who just graduated. Through his speech, this White man seemed to offer the idea of racial equality that underlined the contribution of African American community. In fact, it turned out to be a tendencious speech as this idea was presented because it converged with the personal interest of Mr. Donleavy. He tried to mingle and be accepted in African American community because of political interest.

Donleavy was running for election, and assured our parents that if he won we would count on having the only colored paved playing field in that part of Arkansas. ... He finished, and since there was no need to give any more than the most perfunctory thank-you's, ... (t)hey left with the attitude that now they were off to something really important. (Angelou, 1969, p. 181)

Instead of feeling appreciated, this speech showed how the Whites portrayed the role of African American community. By Donleavy's speech, Angelou realized that there was a huge racial gap that was internalized in the Whites counterparts.

The white kids were going to have a chance to become Galileos and Madame Curies and Edisons and Gauguins, and our boys (the girls weren't even in on it) would try to be Jesse Owenses (an athlete) and Joe Louises (a boxer). Owens and the Brown Bomber were great heroes in our world, but what school official in the white-goddom of Little Rock had the right to decide that those two men must be our only heroes? (Angelou, 1969, p. 179)

This realization reflected the social norms and beliefs that African American community could not hold a reputable position in that era. They were seen as "maids and farmers, handymen and washerwomen" and when they wanted to hold a higher position based on the social norm, it would sound "farcical and presumptuous" (Angelou, 1969, p. 180). This statement should not be seen as job degrading, in which some jobs were considered lower than others. Instead, it shows that some jobs were exclusively performed by some racial groups. Thus, even if the Whites, who were pictured as electorate candidates in Angelou's book, seemed to offer promising future to African American community, it was considered as a mere political agenda. $\mathrm{Mr}$. Donleavy tried to gain voice from African American community, yet his speech showed that he looked down at their community. African American community has struggled for racial equality and the Whites could provide support whenever it converges with their interest. This practice could still be seen occassionally in modern era whenever political ceremonies are held. In struggling over this issue, African American community start to pave their ways in the educational and intellectual realm. By realizing their own identity, they promote intelligence as the new ways to achieve racial equality which has become their objectives over years of struggle. 


\section{c. The Social Construction of Race}

In her book, Angelou gives a clear description of how her race, the African American community, was seen as inferior to the Whites. This belief was constructed by the social and cultural realm of that era. As stated in her book, Angelou (1969) described the segregation in Stamps, Arkansas as "so complete" since most African American children did not know exactly how the Whites looked like (p. 25). They believed that the Whites were different from them, even Angelou described her lack of knowledge of the Whites by stating "I couldn't force myself to think of them as people". For little Angelou at that time, people were those who lived in her area, while the Whites as "the strange pale creatures" were not considered as folks; they were "whitefolks".

People were those who lived on my side of town. I didn't like them all, or, in fact, any of them very much, but they were people. These others, the strange pale creatures that lived in their alien unlife, weren't considered folks. They were whitefolks (Angelou, 1969, p. 26).

This view of the racial matter was not a sudden norm that was attached to each person since they were born. This might be the result of years of beliefs passed from one generation to another. In the context of Angelou's book, she lived in an area predominantly occupied by the African American community. She lived separately from the Whites which made her believe that she was the explorer "walking without weapons into man-eating animal's territory" when she passed the White part of town:

... the last stop before whitefolksville, we had to cross the pond and adventure the railroad tracks. We were explorers walking without weapons into maneating animal's territory. In Stamps the segregation was so complete that most Black children didn't really, absolutely know what whites looked like (Angelou, 1969, p. 25).

She was taught, from the beginning, not to interact with the Whites. Even, she was asked to go and hide anytime the Whites came to her area. All these beliefs and habits were built by people in her community. This was a social construction. African American community was taught to be cautious with their White counterparts and this rule worked the other way around even since very young age. This caution does not emerge without reasons; their community works in the way that puts racial issue on the surface because their social norms are constructed that way. Since these norms are socially constructed, communal efforts are needed to mitigate these racial issues.

\section{d. Differential Racialization}

In her book, Angelou portrays the differential racialization in terms of the threats of violance from racist groups. These threats are experienced exclusively by African American community as a minority group which might be experienced differently by other racial groups in the United States. In the context of Angelou's book, the Whites who belong to a white supremacist group are pictured as the racist. They are members of the organization called $\mathrm{Ku}$ Klux Klan which is also known as KKK. This organization was first formed in the South by former Confederate veterans in 1865 . It was widely known for its underground movement which promoted violence, particularly against African American community. As a white supremacist group, its main objective is to ensure the domination of Whites community over other racial groups. In meeting its 
objective, KKK performs the act of violance, intimidation, and repression towards other racial groups which they consider as threats, particularly African American community.

Angelou depicts the struggle of African American community when facing the KKK, which might be completely different from other racial groups. As described in the book, when a former sheriff named Mr. Steward told Momma that the KKK would come to their area, it created a sense of fear to Angelou and her family:

... I heard him say to Momma, "Annie, tell Willie (Angelou's uncle) he better lay low tonight. A crazy nigger messed with a white lady today. Some of the boys'll be coming over here later." Even after the slow drag of years, I remember the sense of fear which filled my mouth with hot, dry air, and made my body light (Angelou, 1969, pp. 17-18).

During that period of time, African American men were pictured as criminals and terrifying predators who could perform the act of violence towards helpless targets, particularly White women (Pilgrim, 2000). In this modern era, a number of literature portrays that issue as the main theme of discussion. This belief was deeply rooted in the White community which made them believe that African American men were very dangerous and deserved punishment. As a further action, this belief became the very point which was used by the KKK to justify their act of violence towards African American community. African American men, in particular, and African American community in general struggled hard because of this belief. Angelou's depiction of the KKK reflected her community's struggle in dealing with this organization and its brutal actions;
The "boys"? Those cement faces and eyes of hate that burned the clothes off you if they happened to see you lounging on the main street downtown on Saturday. Boys? It seemed that youth never happened to them. Boys? No, rather men who were covered with graves' dust and age without beauty or learning. The ugliness and rottenness of old abominations (Angelou, 1969, p. 18).

On one hand, the words of caution by the former sheriff might save African American men in Angelou's area since they got warning to perform the act of prevention. On the other hand, it showed an unspoken rule in the South area that the KKK could exercise their power freely over African American community. This situation enabled this racist group to create their own rule which could only be applied to African American community, particularly African American men. Angelou portrayed her uneasy feeling towards $\mathrm{Mr}$. Steward's caution which might reflect the differential racialization in her community.

His confidence that my uncle and every other Black man who heard of the Klan's coming ride would scurry under their houses to hide in chicken droppings was too humiliating to hear. Without waiting for Momma's thanks, he rode out of the yard, sure that things were as they should be and that he was a gentle squire, saving those deserving serfs from the laws of the land, which he condoned. (Angelou, 1969, p. 18)

In dealing with this situation, Angelou depicted in her book that her uncle, and all of the African American men in that area, needed to hide in their houses as the act of prevention. If the "boys" found them at that night, they would surely be lynched. These "laws of the land" were exercised by the KKK as the white supremacist group to control African 
American community. Other racial groups might not experience these kinds of laws. Although African American community was repressed even in their land, they tried to resist by building a strong community. Their community got stronger since they always gathered occassionally and Momma's store was one of the places that turned to be a safe place for them. At first, they might not even realize that their gathering would build their own community. In the end, it could become the foundation of their struggle. This act of resistance would then lead to their participation in social movements aimed for fighting their rights and equality of all racial groups.

\section{e. Intersectionality}

Since one's identity is not only based on race alone, other factors intersect with the shaping of someone's identity; class, sex, sexual and political orientation, as well as personal history. This idea is discussed under the concept of intersectionality. This concept is also developed by Kimberlé Crenshaw in 1989. Crenshaw (1989) emphasizes more on the intersection of race and gender which greatly affect the life struggle of African American women, in particular, against discriminatory acts. In the case of Angelou's book, she provides a portrayal of how her identity was defined both by her race and also her sex or gender. Being born as an African American woman, she had to fight against racism towards the African American community in general as well as to struggle for gender equality as a woman (Leitch, 2010, p. 438). At the beginning of the book, Angelou described her feeling as a black little girl who desired to have white's characteristics. She stated, "I was going to look like one of the sweet little white girls who were everybody's dream of what was right with the world" (Angelou, 1969, p. 2). By this statement, Angelou showed her belief that "white equals good and black equals bad". She kept comparing her skinny legs with the legs of the Whites, her kinky black hair with long and blonde hair, and her dirt skin color with the fair one. She believed that what was considered beautiful by society was all the things that she did not have; long legs, blonde hair, and fair skin.

Wouldn't they be surprised when one day I woke out of my black ugly dream, and my real hair, which was long and blond, would take the place of the kinky mass that Momma wouldn't let me straighten? My light-blue eyes were going to hypnotize them ... because my eyes were so small and squinty. ... Because I was really white and because a cruel fairy stepmother, who was understandably jealous of my beauty, had turned me into a too-big Negro girl, with nappy black hair, broad feet and a space between her teeth that would hold a number-two pencil (Angelou, 1969, pp. 2-3).

This belief stayed in her mind and influenced the way she saw herself and shaped her identity. However, as she grew older, she realized that her value was not determined by her looks. She realized that she needed to work on other characteristics which were far more important than feeling sorry for her born-look. She turned to be a woman who understood that her worth was not defined by the stereotypical traits built by the Whites. This was her struggle to get free from the intersectionality, both because of her race and gender.

In this modern era, this belief of 'beauty' norms is still held by society in general and the African American community in particular. African American women start to promote a 
counter-narrative of this belief through a cultural movement known as 'Black is Beautiful'. This movement emerged firstly as a slogan of a fashion show held in 1962. Meeting with huge enthusiasm and acceptance, this fashion show becomes a regular and the movement of 'Black is Beautiful' turns into black nationalism (Sayej, 2019).

\section{f. Voice of Color}

Angelou writes her autobiography as a way to cope with traumatic childhood experiences. At first, she did not want to write about events that happened to her years ago. Yet, James Baldwin and Jules Feiffer, two of her friends, challenged her by saying that writing her experience in a form of autobiography as literature was an impossible thing to work on for her (Lanzendorfer, 2017). Angelou accepted this challenge by working on her first autobiography I Know Why the Caged Bird Sings. When it was first published in 1969, it became a best-seller book and even turned to be one of the most widely read and taught books originally written by an African American (Bauer \& Wightman, 2020). One of the reasons behind this high acceptance and recognition is because it was among the first books that honestly portrays the life of an African American woman who experienced racism first-hand. Maya Angelou holds a better position in writing and speaking up about the issue of race and racism than the White writers because she was directly present in and affected by that situation. She has a privilege to voice up about race and racism, something that is not possessed by the Whites, and many African Americans. This argument is also in line with the nature of Black Aesthetic which helps African American artists "to create, maintain, navigate, and understand" the life experiences of their community (Taylor, 2010, p. 1).

All the basic tenets of critical race theory proposed by Delgado and Stefancic (2001) could be used to discuss and analyze the kinds of oppression experienced by the African American community as well as their struggle against it. Angelou's experiences are not limited to the events which are discussed in this paper. There are many other events and experiences related to race, racism, rape, and oppression that happened to Angelou, particularly during her childhood in the south. Yet, the events which are discussed in this paper could perform as portrayals of how the African American community was oppressed by the Whites, how this oppressed society badly affected African Americans, and how hard the African American community struggled against the oppression.

\section{CONCLUSION}

Black Aesthetic criticism acts as a way to respect African American artists as well as African American literature. It gives a chance for African American literature in any form, ranging from poems to songs, to be treated at the same level as White literature. This type of criticism stands on a belief that the African American community should create their own version of literature as well as literary study which have no relation with the Whites. Like any other literary criticisms, Black Aesthetic also reaches its peak during the mid-1960s to 1970s when many works of African American artists emerged as a way to depict their situation in such an oppressed society. However, there are also various debates from African American artists and theorists over this criticism. The radical ones insist on segregating Black literature from the Whites 
since based on their perspective, Black literature could only be analyzed by the African American community alone. Meanwhile, others try to give ways for any literary critics, regardless of their race and skin color, to conduct a study on Black literature since literature is universal. These debates stay over the years, yet in this modern era, Black Aesthetic criticism turns into one of the most prominent American literary criticism, not only among Black literary critics but also for all critics.

The analysis of Maya Angelou's autobiography entitled I Know Why the Caged Bird Sings under the scope of Black Aesthetic criticism could result in a better understanding of the ways the society worked for either the African American community or the Whites. The discussion in this research shows that the African American community experiences racism in daily basis as the result of years of oppression by the Whites. This racism could be portrayed through five basic tenets proposed by Delgado and Stefancic (2001). Although the issue of racism seems to be inevitable for African American community, various struggles have been done to fight it. If in the past era African American community tend to rely on the act of ignorance, they have gained courage to take actions in this modern era, one of which is through 'Black is Beautiful' movement. These actions should be amplified to achieve more significant changes. Moreover, authorities should take part to tackle racism in American society. After all, the issue of racism is not the problem of African American community alone; it has been society's responsibility.

\section{REFERENCES}

Angelou, M. (1969). I know why the caged bird sings. Bantam Books.
Bauer, P., \& Wightman, J. (2020). I know why the caged bird sings | Summary \& facts. https://www.britannica.com/topic/IKnow-Why-the-Caged-Bird-Sings

Collins, P. H. (2000). Black feminist thought: Knowledge, consciousness, and the politics of empowerment. Routledge.

Crenshaw, K. W. (1989). Demarginalising the intersection of race and sex: A black feminist critique of anti-discrimination doctrine, feminist theory, and anti-racist politics. University of Chicago Legal Forum, 1989(1), 139-167. https://doi.org/10.4324/9781315582924 $\underline{-10}$

Delgado, R., \& Stefancic, J. (2001). Critical race theory: An Introduction. New York University

Press.

https://doi.org/10.1080/10714413.2012. $\underline{735558}$

Guess, T. J. (2006). The social construction of whiteness: Racism by intent, racism by consequence. Critical Sociology, 32(4), 649-673.

https://doi.org/10.1163/1569163067791 $\underline{55199}$

Ladson-Billings, G. (1998). Just what is critical race theory and what's it doing in a nice field like education? International Journal of Qualitative Studies in Education, 11(1), 7-24. https://doi.org/10.1080/0951839982368 $\underline{63}$

Lanzendorfer, J. (2017). 11 Facts about "I know why the caged bird sings". Mental floss.

https://www.mentalfloss.com/article/75 541/11-facts-about-i-know-why-cagedbird-sings

Leitch, V. B. (2010). American literary criticism since the 1930s (Second ed.). Routledge.

McConahay, J. B., Hardee, B. B., \& Batts, V. (1981). Has racism declined in America? Journal of conflict resolution, 25(4), 563-579. 
https://doi.org/10.1177/0022002781025 $\underline{00401}$

Pilgrim, D. (2000). The Brute Caricature - Jim Crow Museum - Ferris State University. https://www.ferris.edu/jimcrow/brute/

Sayej, N. (2019). Black is beautiful: Celebrating the significance of Kwame Brathwaite. The guardian. https://www.theguardian.com/artandd esign/2019/mar/26/kwame-brathwaitephotographer-black-is-beautiful

Sethi, A. (2013). I know why the caged bird sings by Maya Angelou - Review. The guardian.

https://www.theguardian.com/books/2 013/aug/18/maya-angelou-caged-birdreview

Sniderman, P. M., Piazza, T., Tetlock, P. E., \& Kendrick, A. (1991). The new racism. American journal of political science, 35(2), 423.

https://doi.org/10.2307/2111369

Taylor, P. (2010). Black aesthetics. Philosophy compass, 5(1), 1-15. https://doi.org/10.1111/j.17479991.2009.00263.X

Tidwell, B. J. (1990). The price: A study of the costs of racism in America. National Urban League, Inc.,

Tyson, L. (2006). Critical theory today: A user-friendly guide (Second ed.). Routledge.

Wellek, R., \& Warren, A. (1954). Theory of literature (Third ed.). Jonathan Cape. 